\title{
KATALOG TORUŃSKIEGO KSIĘGARZA SAMUELA JANSSONA MÖLLERA Z 1738 ROKU W ZBIORACH BIBLIOTEKI KATEDRALNEJ W GNIEŹNIE
}

\begin{abstract}
Streszczenie
W artykule zaprezentowana została oferta księgarska Samuela Janssona Möllera, księgarza działającego w Toruniu w pierwszej połowie XVIII wieku. Podstawą do jej przedstawienia był katalog księgarski z 1738 roku, znajdujący się w zbiorach Biblioteki Katedralnej w Gnieźnie. Jansson Möller związał się z Toruniem ok. 1725 roku, zatrudniając się w prężnie działającej księgarni Jana Chrystiana Laurera, po którego śmierci na prośbę wdowy prowadził ją dalej do ok. 1751 roku, kiedy zmarł. W katalogu zostało wykazanych prawie 1600 pozycji, z czego ponad połowa to książki wydane w XVII wieku, 35\% pochodziło z pierwszych dekad XVIII stulecia, a pozostałe to druki XVI-wieczne, co dowodzi, że księgarz na równi z nowymi wydawnictwami handlował książką używaną. Pod wieloma względami analizowany katalog pokazywał, że Jansson działalnością nawiązywał do swego poprzednika i innego księgarza toruńskiego tego okresu, Jana Fryderyka Hauensteina. W katalogu ponad 20\% książek stanowiły polonika, w tym sporo pozycji polskojęzycznych. Mimo że elity rządzące i intelektualne miasta to $\mathrm{w}$ tamtym czasie głównie protestanci, Jansson zwracał się ze swą ofertą także do katolików, co pokazuje, że społeczność katolicka musiała wykazywać zainteresowanie książkami w porównywalnym stopniu, co protestancka.
\end{abstract}

Słowa kluczowe: Jansson Möller Samuel; księgarstwo; katalog księgarski; Toruń; XVIII w.; Biblioteka Katedralna w Gnieźnie

Spośród trzech księgarzy działających w Toruniu w pierwszej połowie XVIII wieku: Jana Fryderyka Hauensteina, Jana Chrystiana Laurera i Samuela Janssona Möllera najmniej dotąd poświęcono uwagi temu ostatniemu. Przyczyn takiego

\footnotetext{
* Iwona Imańska - prof. nauk humanistycznych; Instytut Badań Informacji i Komunikacji; Uniwersytet Mikołaja Kopernika w Toruniu; e-mail: iwim@umk.pl

https://orcid.org/0000-0003-0253-7170
} 
stanu rzeczy należy zapewne upatrywać w tym, że po jego pobycie w Toruniu zachowało się niewiele dokumentów. Wiemy, że zorganizował aukcję książek i że po jego śmierci asortyment księgarski został wystawiony na licytację, ale ani jeden, ani drugi katalog aukcyjny nie zachowały się. Wiadomo też było, że w 1738 roku opublikował katalog księgarski, o którym wspominał badacz dziejów książki w staropolskim Toruniu Zygmunt Mocarski, informując jednocześnie, że druk ten był w posiadaniu Biblioteki Kapitulnej w Gnieźnie ${ }^{1}$. Jednak po II wojnie światowej ślad po katalogu zaginą $1^{2}$. Dopiero prace prowadzone w ostatnich latach w Bibliotece w ramach realizacji grantu „Inwentaryzacja zasobu Biblioteki Katedralnej w Gnieźnie" ujawniły ten druk ${ }^{3}$. Mając zatem dostęp do katalogu, warto na jego podstawie przeanalizować asortyment księgarni i przybliżyć działalność S. Janssona Möllera w Toruniu.

Samuel Jansson Möller pochodził z holenderskiej drukarsko-księgarskiej rodziny Jansson van Waesberge. W latach 80. XVII wieku przybyli do Gdańska Aegidius i jego brat Johannes. Uruchomili księgarnię przy ul. Długiej, blisko ratusza. W rękach rodziny firma działała do 1767 roku. Samuel był synem Aegidiusa, z Toruniem związał się od ok. 1725 roku, zatrudniając się w księgarni Laurera ${ }^{4}$. Nie posiadał obywatelstwa Torunia ${ }^{5}$, mimo to po śmierci Laurera wdowa powierzyła mu kierowanie księgarnią. Zmarł w końcu 1750 lub na początku 1751 roku, gdyż już w połowie marca 1751 roku wystąpiono do Rady miejskiej o udzielenie zgody na przeprowadzenie aukcji pozostawionego przez niego dobytku oraz ksią$\dot{z ̇ e k}^{6}$. Zasoby księgarni licytowane były od 14 września tego roku ${ }^{7}$.

Samuel Jansson w niewielkim stopniu dał się poznać także jako nakładca. Wiemy o co najmniej jednej książce opublikowanej jego sumptem. Była to popularna praca dominikanina i panegirysty Bernarda Mercatora Nucleus Catecheticus (Kolonia 1713). Książka znana była już toruńskiemu czytelnikowi, gdyż kilka lat wcześniej, w 1692 roku na jej wydanie zdecydował się J.Ch. Laurer.

${ }^{1}$ Z. Mocarski, Ksiązka w Toruniu do roku 1793. Zarys dziejów, Toruń 1934, s. 84.

2 J. Rudnicka, Bibliografii katalogów księgarskich wydanych w Polsce do końca wieku XVIII, Warszawa 1975, s. 203-204, poz. 640. Autorka wprawdzie odnotowała ten katalog, ale jako wydawnictwo J.Ch. Laurera, podając skrócony opis druku i wszelkie o nim informacje na podstawie książki Mocarskiego.

${ }^{3}$ Grant finansowany był przez Narodowy Program Rozwoju Humanistyki MNiSW (nr: 11H 12 0179 81), a jego efektem jest też katalog on-line starych druków tej biblioteki.

${ }^{4}$ A Jaworek, Janssonius, w: Stownik pracowników ksiązki polskiej, red. I. Treichel, Warszawa 1972, s. 364.

${ }^{5}$ Jansson popadł w konflikt z introligatorami toruńskimi w 1744 roku, którzy zwrócili m.in. uwagę na to, że nie jest on obywatelem Torunia, ten zapewniał wówczas, że ma zamiar starać się o nie. Por. Archiwum Państwowe w Toruniu (dalej: AP Tor.), sygn. Kat. II, II. 45a, Acta consularia. Beilagen, k. 332-333.

${ }^{6}$ AP Tor., sygn. Kat. II, II 49, Acta consularia, k. 45-45v.

${ }^{7}$ Zgodnie $\mathrm{z}$ regulaminem aukcji książek w Toruniu, opublikowano katalog licytowanych zbiorów, znany jedynie z krótkiego opisu: Bibliotheca varii generis et copia polonica in aedibus nunc Kewertianis etc.... a 1751 d. 13 Sept. et seqq. publica auctionis lege venalis, Thorunii [1751]. Por. I. Imańska, Toruńskie aukcje książek w XVIII wieku, Toruń 2007, s. 82-83. 
Samuel Jansson zanim przejął księgarnię J.Ch. Laurera, pracując u niego, współpracował z wieloma kolekcjonerami książek, pomagając w kompletowaniu ich bibliotek. Szczególnie pomocny był w zakupach na aukcjach księgarskich. Tu wyróżniały się jego kontakty z referendarzem koronnym, a następnie biskupem kijowskim Józefem Andrzejem Załuskim. Jak one przebiegały, dowiadujemy się z ich korespondencji, z której wynika, że współpraca rozpoczęła się ok. 1729 roku. Jansson reprezentował interesy Załuskiego w pierwszej kolejności w Toruniu, ale także na aukcjach w Gdańsku i niekiedy w Amsterdamie. Informował referendarza koronnego o planowanych licytacjach, wysyłał mu wydrukowane katalogi aukcyjne, a otrzymawszy od Załuskiego odpowiednie dyspozycje, licytował zgodnie $\mathrm{z}$ jego wytycznymi ${ }^{8}$. Jako księgarz starał się zainteresować biskupa swoją ofertą księgarską, polecając $\mathrm{w}$ jednym $\mathrm{z}$ listów $\mathrm{z}$ marca 1749 roku ok. 20 tytułów książek polskich. Mniej więcej w tym samym czasie przyjął do swojej księgarni 9-10 egzemplarzy Opera omnia Pawła Potockiego, dzieła wydanego w 1747 roku z inicjatywy Załuskiego'.

Jako księgarz Jansson zajmował się sprzedażą przede wszystkim nowych wydawnictw, ale nie stronił także od książki antykwarycznej, czego dowody mamy w opublikowanym katalogu, o którym więcej poniżej. Zorganizował też jedną aukcję książek w połowie października 1740 roku $^{10}$. Z zachowanych źródeł wynika, że część nowości sprzedawał w oprawach, które według miejscowych introligatorów wykonywali dla niego Żydzi w Kaliszu, Bydgoszczy i Poznaniu. Nie podobało się to toruńskim fachowcom, gdyż w ten sposób narażeni byli na utratę zarobków. Do tego bardzo negatywnie oceniali efekty pracy konkurentów spoza miasta. Podobnie było w wypadku sprzedawanych przez Janssona kalendarzy, które jego poprzednicy oferowali w broszurze, a on miał je oprawne. W związku z tymi zarzutami w listopadzie 1744 roku złożyli na księgarza skargę do Rady, która dążyła do polubownego załatwienia problemu. $Z$ wniesionej supliki i wyjaśnień Janssona wynika, że księgarz współpracował również z miejscowymi introligatorami: z Kasprem Gotfrydem Ernstem i Jeremiaszem Tiellichem, lecz ich stosunki nie zawsze układały się poprawnie ${ }^{11}$.

Swoich klientów Jansson starał się w różny sposób przyciągnąć do księgarni, korzystając $\mathrm{z}$ dostępnych wówczas środków promocji, w tym tych najprostszych, jak wywieszanie nowości przed drzwiami swego lokalu. Nie mógł zamieszczać anonsów w prasie, ponieważ w Toruniu gazety informacyjne i ogłoszeniowe w pierwszej połowie XVIII wieku jeszcze nie wychodziły, poszedł więc w ślady poprzedników i publikował katalogi księgarskie. Jedyny zachowany to właśnie

${ }^{8}$ I. Imańska, Sprawy ksiązki w listach do Józefa Andrzeja Załuskiego od jego korespondentów z Prus Królewskich, w: Bracia Załuscy: ich epoka i dzieło. Zbiór studiów, red. D. Dukwicz, Warszawa 2011 , s. $157-158$.

${ }^{9}$ Listy S. Janssona Möllera do J.A. Załuskiego z Torunia z 9 III i 22 VI 1749 r., Biblioteka Narodowa w Warszawie (BN), rkps, III 3249. Por. też P. Buchwald-Pelcowa, Drukowi winniśmy oświecenie naszego wieku...Rola książki w drodze ku Oświeceniu, Warszawa 2003, s. 109.

${ }^{10}$ AP Tor., sygn. Kat II, II, 41, Acta consularia, k. 68.

${ }^{11}$ AP Tor., Kat. II, II 45a, k. 331, 332 - 333; Mocarski, Książka w Toruniu, s. 114. 
katalog z 1738 roku ze zbiorów Biblioteki Katedralnej w Gnieźnie ${ }^{12}$. Informacja na karcie tytułowej wskazuje, że planował publikować następne. Nie wiemy, czy do tego doszło, ponieważ źródła na ten temat milczą. Wydany w 1738 roku katalog Janssona stroną formalną nie odbiegał od innych takich publikacji: była to broszurka formatu ósemki, o objętości 57 kart nieliczbowanych. Po tytulaturze księgarz skierował kilka słów do klientów, zwracając się w ostatnim zdaniu z propozycją dostarczania mu rękopisów łacińskich lub polskich, które gotów był opublikować po przystępnej cenie. Spisane w katalogu książki zostały ułożone w kolejności alfabetycznej według autorów, ewentualnie tytułów. W ten sposób wyszczególnionych zostało 1560 pozycji. Podstawowy zrąb poprzedził wykaz książek do użytku kościelnego (Libri ad usum Ecclesiae - 38 pozycji), a zakończył dodatek (Appendix - 56 książek), co razem dało prawie 1600 druków (1594). Opisy katalogowe poszczególnych pozycji również nie odbiegały od powszechnie przyjętych: były krótkie, ograniczały się do podania nazwiska autora i imienia w nawiasie, skróconego tytułu, formatu, miejsca i roku druku, liczby tomów i ewentualnie zasygnalizowano istniejące w książce ilustracje. Nie wszystkie z wymienionych elementów tytulatury występowały za każdym razem. Najczęściej nie ma miejsca druku, zdarzały się też błędne dane, np. pomyłki w roku wydania. Całkowicie pomijano jeszcze takie składowe opisu jak objętość dzieła, nazwisko drukarza czy nakładcy oraz cenę. Brak było także informacji o oprawie, szczególnie w wypadku książek z wieków XVI i XVII, które zapewne pochodziły z drugiej ręki i należy przypuszczać, że w większości ich poprzedni właściciel postarał się o oprawę.

Przyglądając się tej ofercie od strony formalnej, należy odnotować, że pod względem chronologii wydawniczej dominowały publikacje z XVII wieku, których było niewiele ponad 900, co stanowiło prawie 57\% całości. Warto tu jednak podkreślić zdecydowaną przewagę $\mathrm{w}$ tej grupie książek wydanych $\mathrm{w}$ drugiej połowie XVII stulecia. Było ich prawie 670, gdy tych z pierwszych pięciu dekad niecałe 250. Najnowszych wydawnictw, tłoczonych od 1701 roku po koniec lat 30. XVIII stulecia w katalogu odnotowanych zostało niemal 560, czyli $35 \%$. Biorąc pod uwagę fakt, że książki wówczas nie starzały się tak szybko jak obecnie, należy sądzić, że te z ostatnich dziesięcioleci XVII wieku mogły cieszyć się jeszcze sporym zainteresowaniem klientów. Jansson Möller w omawianym spisie umieścił jeszcze prawie pół setki druków z XVI stulecia. Zapewne większość książek z wieków XVI i szczególnie z pierwszej połowy XVII były to książki używane. Ich obecność w księgarniach staropolskich wynikała po trosze $\mathrm{z}$ faktu, że w tym czasie nie było jeszcze wyspecjalizowanego handlu antykwarycznego, a w tym przypadku mogła być jeszcze wypadkową zainteresowań księgarza dawną książką, czego potwierdzeniem było organizowanie przez niego aukcji książek i pośredniczenie w imieniu Załuskiego i innych kolekcjonerów w licytacjach antykwarycznych.

${ }^{12}$ Catalogus librorum varii generis qui venales prostant in officina B. J. C. Laureri viduae curante Samuele Janssonio filio, Pars prima, Thorunii in lata Platea vulgo Breiten - Gasse dicta 1738, [Torun 1738], egz. w Bibliotece Katedralnej w Gnieźnie, sygn. BK 2699. 
Najwięcej oferowanych druków wytłoczonych zostało w różnych miastach niemieckich, na czele $z$ Kolonią i Frankfurtem nad Menem. Księgarz miał też wydawnictwa francuskie (głównie z Lyonu i Paryża), tłoczone w Niderlandach (Antwerpia, która była ważnym ośrodkiem druku książek liturgicznych, i Amsterdam), sporadycznie włoskie (Wenecja, Rzym), szwajcarskie (Bazylea, Genewa, ale głównie z wieków XVI i XVII), a nawet z Londynu. Niemal 20\% książek spisanych w katalogu jako miejsce wydania podane miało ośrodek polski i - co ciekawe - nie był to tylko Toruń czy Gdańsk. Jansson zgromadził książki, a częściowo sam sprowadzał prawie z wszystkich ówcześnie działających drukarni, najwięcej z Krakowa i Warszawy, a także z Braniewa, Wilna, Częstochowy, Poznania, Kalisza, Lublina, z miast, gdzie funkcjonowały przeważnie tylko oficyny zakonne, należące najczęściej do jezuitów, nastawione w pierwszej kolejności na druk wydawnictw dla potrzeb Kościoła katolickiego.

Pod względem językowym oferowane książki to w ponad $86 \%$ publikacje łacińskojęzyczne, uzupełnione o kilkadziesiąt druków w języku niemieckim i ponad 180 (ponad 11\%) polskojęzycznych oraz kilkanaście dwujęzycznych, np. niemiecko-polskie.

Tematycznie oferta Janssona była urozmaicona i skierowana do różnorodnych klientów. Jej główną część stanowiła książka religijna. Ta partia asortymentu w dużym stopniu nakierowana była na klientelę katolicką, ale nie zabrakło również piśmiennictwa protestanckiego. Katalog otwierał wykaz 38 ksiąg liturgicznych przeznaczonych do użytku Kościoła powszechnego i polskiego, jak brewiarze czy mszały ${ }^{13}$.

W tym dziale oferował Jansson jeszcze kilka edycji Biblii, w tym dwie w języku polskim: tzw. Biblię Radziwiłłowską, kalwińskie wydanie dokonane w Brześciu Litewskim w 1563 roku i jej nowe, poprawione wydanie, czyli Biblię gdańską z 1632 roku wydrukowaną czcionkami warsztatu Andrzeja Hünefelda i przeznaczoną do szerszego upowszechnienia. Gdańskie przedsięwzięcie różniło się nie tylko rewizją poprzedniego przekładu, ale i stroną wydawniczą, gdyż drukarz zdecydował się na opublikowanie Biblii w jednym woluminie w formacie octavo, a nie w najczęściej stosowanym folio ${ }^{14}$. Biblia drukowana przez Hünefelda była wznawiana w 1726 roku w Halle i w 1738 roku w Królewcu, ale egzemplarzy $\mathrm{z}$ tych edycji $\mathrm{w}$ omawianym katalogu nie było. Katolicy mieli do wyboru u Janssona jedną z dwóch Wulgat, w wydaniach z początku XVIII stulecia: Wulgatę sykstyńską lub Wulgatę klementyńską ${ }^{15}$. Biblistykę reprezentowały

${ }^{13}$ Np. Breviarum romanum ex decreto Sacrosancti Concilii Tridentini restitutum, S. Pii V. Pontificis Max. jussu editum, Antverpiae 1734 (opis w katalogu wskazuje na Wenecję jako miejsce druku); Officia propria sanctorum et sanctarum tam de praecepto, quam ad libitum, Kraków 1713; Missae propriae patronorum et festorum Regni Poloniae. Ad normam missalis Romani accomodatae, b.m. i r. dr.

${ }^{14}$ Z. Nowak, Gdańska drukarnia Guillemota-Hünefelda $w$ stużbie polskiej reformacji (1603 -1652), w: tenże, Po stara księgę sięgam ze wzruszeniem. Szkice z dziejów i kultury książki w Prusach Królewskich od XV do XVIII wieku, Gdańsk 2008, s. 177-182.

${ }^{15}$ Biblia Sacra Vulgatae editionis Sixti V..., Norimbergae 1714; Biblia Sacra Vulgatae editionis Sixti V. et Clementis VIII..., Antverpiae 1716. 
jeszcze w tej ofercie m.in.: Nowy Testament wydany w Hamburgu w 1664 roku i poetycka parafraza Jana Kochanowskiego Psałterza Dawidów w edycji krakowskiej $^{16}$. Cały tekst Pisma Świętego w pewnym stopniu zastępowały wiernym historie biblijne, znane w Europie od XVII wieku. Klient księgarni toruńskiej mógł w tym wypadku nabyć opowieść biblijną Francuza Nicolasa Fontaine’a, którą na język polski przetłumaczył biskup Andrzej Chryzostom Załuski. Historię Starego i Nowego Testamentu $z$ wykładem z oycow świętych zebranym dwukrotnie: w 1708 i 1709 roku tłoczyli jezuici w Braniewie, a u Janssona były egzemplarze $\mathrm{z}$ drugiego wydania.

Księgarz toruński miał na składzie też kilka prac poświęconych historii Kościoła. Znalazła się wśród nich Ecclesiasticae historiae libri decem (Moguncja 1672) Euzebiusza z Cezarei, uważanego za twórcę dziejopisarstwa kościelnego, której współwydawcą był związany również krótko z Toruniem Szymon Beckenstein. $\mathrm{Z}$ twórców nowożytnych na uwagę zasługują prace historyka francuskiego Claude'a Fleury, ale nie słynna Histoire ecclésiastique, a Catéchisme historique w wersji niemieckojęzycznej, książka wydana we Frankfurcie pt. Historischer Catechismus (Frankfurt 1727) i Institutiones Iuris Ecclesiastici (Frankfurt i Lipsk 1724) oraz dwie autorstwa innego francuskiego historyka Kościoła, Louisa Maimbourga w przekładzie na język polski: Historya o krucyatach na wyzwolenie Ziemie Świętey (Kraków 1707) i Historya o herezyi obrazoboycow y przeniesieniu Państwa Rzymskiego do Francuzow (Kraków 1717). Polską twórczość w tym zakresie reprezentowały dzieła Piotra Skargi i Jana Kwiatkiewicza. Pierwszego Roczne dzieie kościelne od narodzenia Pana y Boga Jezusa Christusa (Kraków 1607) to thumaczenie dzieła Annales Ecclesiastici Cezarego Baroniusa, które to Skarga dostosował do potrzeb walki z herezją, skracając niektóre fragmenty, a uwypuklając te, które mówiły o walce kolejnych synodów z wyznawcami herezji ${ }^{17}$. Jej kontynuacja pt. Roczne dzieie kościelne od Roku Pańskiego 1198 aż do lat naszych (Kalisz 1695) pióra jezuity Kwiatkiewicza powstała za namową biskupa A.Ch. Załuskiego.

Nie zabrakło wśród polecanych przez Janssona książek prac z teologii moralnej i ascetycznej. Zwraca tu uwagę przede wszystkim sporo pism autorów polskich, takich jak: jezuita Kasper Drużbicki, którego twórczość znana była także poza Polską, głównie w Niemczech i Holandii, czy również jezuici Jan Drews oraz Tomasz Młodzianowski, bardziej znany jako kaznodzieja. Księgarnia toruńska polecała jego pisma ascetyczne, w tym wielokrotnie publikowane Rozmyslania albo lekcya duchowna (Lublin 1699). Każdego z nich na półkach księgarni stało po kilka książek. Spośród obcych autorów część ich dzieł posiadał Jansson w oryginale, część w przekładzie na język polski. Prace oryginalne to dwa podręczniki

${ }^{16} \mathrm{~W}$ katalogu podana data druku to 1686 rok. Takiego wydania nie rejestrują znane mi bibliografie i katalogi bibliotek. Prawdopodobnie chodzi o rok 1586. P. Buchwald-Pelcowa we wstępie do faksymile Psałterza podaje, że po roku 1641 przerwano jego wznawianie w przekładzie Kochanowskiego. Por. P. Buchwald-Pelcowa, Wstęp, w: Psałterz Dawidów przektadania Jana Kochanowskiego, Warszawa 1985, s. VII.

${ }^{17}$ J. Tazbir, Skarga Piotr, w: Polski Stownik Biograficzny (dalej PSB), t. 38, red. H. Markiewicz Warszawa-Kraków 1997-1998, s. 41. 
teologii moralnej autorstwa Hermanna Busenbauma Medulla Theologiae Moralis (Padwa 1737) i Theologiae moralis (Kolonia 1729) oraz trzy dzieła Jana Nadasi z Tyrnawy, ale wszystkie wydane na ziemiach polskich: dwie w Braniewie (Vita et mores Praedestinatorum z 1701 i Annus coelestis z 1716), jedna w Krakowie (Mensis divini amoris, 1660). Z kolei klient zainteresowany twórczością Tomasza à Kempis mógł nabyć jego Opera omnia (Kolonia 1682), ale i najpopularniejsze dzieło tego niemieckiego zakonnika i mistyka $O$ naśladowaniu Chrystusa, dostępne po łacinie w edycji z 1730 roku z ilustracjami i w tłumaczeniu na język polski. Tu do wyboru było wydanie poznańskie z 1682 roku i w przekładzie księdza Józefa Trzebieńskiego z 1724 roku, z drukarni warszawskich pijarów. Również twórczość ascetyczna francuskiego jezuity Jeana Crasseta znana była w Rzeczypospolitej w polskiej wersji językowej. Katalog omawianej księgarni odnotowuje wydanie braniewskie z 1707-1708 roku Uwagi chrzescianskie albo rozmyślania krótkie na wszytkie dni roku y swięta uroczyste w thumaczeniu biskupa A.Ch. Załuskiego. Na język polski tłumaczono jeszcze utwory niemieckiego kaznodziei i pisarza ascetycznego, Jeremiasa Drexelliusa. Janssonius miał na stanie po polsku jego Oko wiecznosci (Kraków 1638) i Droga do wiecznosci (Kraków 1632), ale też aż trzy różne edycje zbiorowe jego prac, Opera omnia (Antwerpia b.r., Lejda 1675 i Moguncja 1680).

Inne sektory książki religijnej były także reprezentowane $\mathrm{w}$ asortymencie toruńskiego księgarza. W wypadku hagiografii np. znajdujemy podstawowe dzieło w polskiej literaturze żywotopisarstwa do poznania świętych Kościoła powszechnego, jakim były Żywoty świętych P. Skargi. Jansson oferował najnowszą edycję z 1700 roku z Poznania. Znacznie bogatszy był wybór w przypadku homiletyki. Zainteresowani mogli nawet nabyć Jakuba Wujka Postyllę katolicka na niedziele $i$ święta $\mathrm{w}$ edycji krakowskiej z 1584 roku oraz również z tego okresu Marcina Białobrzeskiego Postilla orthodoxa, to jest wyktad świętych ewangelii niedzielnych $i$ świat uroczystych na cały rok (Kraków 1581), w której autor, przeciwnik arian, nie ustrzegł się polemiki z nimi ${ }^{18}$, i Szymona Starowolskiego Wieniec Niewiędnieiacy Przeczystey P. Mariey Zamykaiacy w sobie Kazania Na wszytkie iey Swięta doroczne z 1649 roku. Jansson miał jeszcze na składzie sporo kazań współczesnych duchownych, w tym wydany nakładem poprzedniego właściciela księgarni Laurera, obszerny dwutomowy zbiór kazań franciszkanina Michała Łosiewicza Pastwa słowa Bożego (Toruń 1706-1708), a także m.in. zbiory kazań Stefana Wielowiejskiego czy Jana Schröttera i Adama Naramowskiego, kaznodziei, którego charakteryzował obrazowy styl i pusta retoryka. Płomienny styl i zaskakująca gra słów cechowała też kazania Franciszka Kowalickiego, autora aż pięciu zbiorów kazań ${ }^{19}$.

${ }^{18}$ M. Brzozowski, Białobrzeski Marcin, w: Encyklopedia katolicka, t. 2, red. F. Gryglewicz, R. Łukaszyk, Z. Sułowski, Lublin 1976, kol. 365-366.

${ }^{19}$ S. Wielowieyski, Kazania o męce Pańskiey, Toruń 1711; J. Schrötter, Sermones ascetici, Brunsberga 1705; A. Naramowski, Sekret poboznosci z utajonych cnot S. S. fundatorow zakonnych wyczerpniony..., Wilno 1723; F. Kowalicki, Katedra kaznodzieie niedzielnego na rok caty, Sandomierz 1725. 
Podobnie jak u poprzedników Janssona, Hauensteina i Laurera, zadziwiała w tej ofercie spora grupa modlitewników i innych książek dewocyjnych w języku polskim. Były wśród nich modlitewniki zawierające modlitwy na różne okazje, pory dnia i okoliczności, książki do nabożeństwa itp. Jako przykłady można tu przytoczyć: Wybór modlitw przy różańcowym nabożeństwie, Modlitwy nabożne św. Gertrudy, Nauki duchowne życia pobożnego S. Wielowieyskiego, Konstancji Lubomirskiej Krótkie zebranie różnego nabożeństwa czy Nauka dobrego i szczęśliwego umierania ${ }^{20}$. Do tego rodzaju publikacji można jeszcze dodać kilka prac Ambrożego Nieszporkowicza, propagatora kultu maryjnego. Na półkach księgarni Janssona znajdował się zarówno Officina Emblematum... (Kraków 1691), rodzaj traktatu mariologicznego, jak i jego najpopularniejsze dzieło, praca poświęcona kultowi Matki Bożej i jej roli w Kościele w wersji łacińskojęzycznej (Analecta mensae Reginalis, Kraków 1681) i po polsku (Odrobiny stołu królewskiego Panny Mariey, Częstochowa 1720).

Piśmiennictwo świeckie prezentowało się równie ciekawe. Jansson proponował swoim klientom bogaty wybór książek z zakresu historii, polityki i prawa. Miał spory zapas wydawnictw szkolnych oraz literatury o charakterze poradnikowym i literatury pięknej. W omawianym katalogu zostało odnotowanych również kilkadziesiąt książek wybitnych myślicieli europejskich od renesansu, począwszy po XVIII stulecia. Na półkach znajdowało się najczęściej po kilka tytułów prac Erazma z Rotterdamu, Niccolò Machiavelliego, Jeana Bodina, Hugo Grotiusa, Justusa Lipsiusa czy Gottfrieda Leibniza i Samuela Pufendorfa. Księgarz dzieła tych autorów miał w wydaniach starszych, nawet XVI-wiecznych, ale też z pierwszych dekad XVIII stulecia ${ }^{21}$.

Czytelnik chcący nabyć u niego dzieła historyczne mógł wybierać spośród prac autorów tworzących od starożytności po czasy współczesne. Z dzieł tych pierwszych katalog wykazywał głównie prace rzymskich dziejopisarzy, jak: Józef

${ }^{20}$ Nie we wszystkich przypadkach udało się ustalić identyfikację bibliograficzną. Np. Wybór modlitw przy różańcowym nabożeństwie w Bibliografii polskiej Estreicherów (t. 33, Kraków 1939, s. 418) to wydanie z Braniewa z 1712 roku, a w katalogu nie podano miejsca druku, zaś rok to 1735. Wspomniana bibliografia nie notuje również Modlitw nabożnych św. Gertrudy, wg katalogu opublikowanych w Poznaniu w 1736 roku. Z kolei R. Bellarmina Nauka dobrego y szczéśliwego umierania Bibliografia polska (t. 12, Kraków 1891, s. 449) odnotowuje wydanie z 1628 roku, a w katalogu podano Kraków 1675. Pozostałe to: S. Wielowieyski, Nauki duchowne życia pobożnego y modlenia się pobożnego, Toruń 1710; K. Lubomirska, Krótkie zebranie różnego nabożeństwa, Kraków 1730 (takie dane podaje katalog, wg Bibliografii Polskiej, t. 21, Kraków 1906, s. 453, pierwsza edycja nie miała podanego roku i miejsca druku, druga ukazała się w Krakowie w 1751 roku).

${ }^{21}$ Można tu wymienić dla przykładu następujące dzieła: Erazm z Rotterdamu, De conscribendis epistolis opus, Norimbergae 1732 i Dialogus de recta Latini Graecique sermonis pronuntiatione, Lugduni Batavorum 1643: N. Machiavelli, De arte militari libri septem, Argentorati 1610, Princeps, Amstelaedami 1699 i Disputationum de republicaquas discursus nuncupavit libri III, Ursellis 1599: J. Bodin, De Republica libri sex, Francofurti 1622; H. Grotius, De Jure belli ac pacis libri tres, Ultrajecti 1696: J. Lipsius, Monita et exempla politica libri duo, (dzieło to miało klika wydań, jednak w opisie katalogowym brak danych o m. i r. dr.) i Opera omnia, Vesallae 1675; G. Leibniz, Principia philosophiae, more geometrico demonstrata, Francofurti, Leipzig 1728; S. Pufendorf, De officio hominis et civis juxta legem naturalem libri duo, Francofurti ad Moenum 1734. 
Flawiusz, Tacyt, Pliniusz Starszy, Titus Liwiusz i Swetoniusz. Greckich historyków reprezentował Tukidydes ze swym dziełem poświęconym wojnie peloponeskiej i historyk czasów cesarstwa rzymskiego, Herodian ${ }^{22}$. Dość liczne włączenie książek tych twórców do oferty księgarskiej, i to zarówno w dawnych wydaniach, jak i z początku XVIII stulecia, wynikało zapewne z ciągłej ich obecności w programach szkolnych.

Pozostałe książki historyczne, szczególnie w wypadku dzieł autorów polskich lub spraw polskich dotyczących, to w dużej mierze wydawnictwa starsze, opublikowane nawet w XVI lub pierwszej połowie XVII stulecia. XVI-wieczny rodowód miały np. trzy prace poświęcone historii Polski: Chronica Polonorum Macieja Miechowity, egzemplarz z krakowskiej oficyny Hieronima Wietora z 1521 roku, wydania niekwestionowanego, poprawionego przez autora; Aleksandra Gwagnina Rerum Polonicarum tomi tres (Frankfurt 1584) i De origine et rebus gestis Polonorum libri XXX Marcina Kromera. Kromer był chyba najbardziej znanym dziejopisarzem polskim piszącym po łacinie, także poza granicami Rzeczypospolitej. Wspomniana praca, począwszy od 1555 roku, kilkakrotnie była tłoczona w Bazylei przez uznaną oficynę Johannesa Oporina. W Toruniu był dostępny także jej przekład na język polski dokonany przez Marcina Błażewskiego, O sprawach, dzieiach y wszytkich inszych potocznosciach koronnych polskich ksiag $X X X^{23}$. Wiele dzieł historycznych opublikowanych w pierwszej połowie XVII stulecia to druki, które zostały wydane nakładem gdańskiego księgarza i wydawcy Jerzego Förstera. Jego wydawnictwa, wzorowane na pracach czołowych niderlandzkich firm, cechował mały format i ozdobne miedziorytowe frontyspisy, których wykonanie powierzał wybitnym miejscowym artystom, takim jak: Jeremiasz Falck czy Andrzej Stech. Gdański bibliopola specjalizował się w publikowaniu dzieł znanych autorów polskich żyjących w XVI i XVII wieku, wśród nich badaczy zajmujących się sprawami historycznymi i politycznymi ${ }^{24}$. W księgarni Janssona z jego dorobku wydawniczego dostępne były trzy prace Andrzeja Maksymiliana Fredry (Gestorum populi Poloni sub Henrico Valesio i Scriptorum Seu Togae et Belli Notationum Fragmenta z 1660 roku oraz Monita politico-moralia et icon ingeniorum z 1664), dwie Stanisława Kobierzyckiego (Historia Vladislai Poloniae et Sueciae principis z 1655 roku i Obsidio Clari Montis Częstochoviensis z 1659), po jednej Arona Olizarowskiego (De politica hominum societate libri tres, 1651), Stanisława Orzechowskiego (Annales, 1643), Joachima Pastoriusa (Bellum Scy-

${ }^{22}$ J. Flavius, Opera omnia, Basel 1582 i Opera, Basileae 1544; Plinius Secundus, Historia naturale, Basil 1530; Titus Livius, Historiarum libri, Amsterdam 1635; Gaius Suetonius Tranquillus, Caesarum XII. Vitae, Nec non Libri de claris Grammaticis et de Claris Rhetoribus, Lipsi 1722; Publius Cornelius Tacitus, Opera quae exstant, Antverpiae 1648 i Opera, Venetiis 1707-1708; Tucidides, De bello Peloponnesisco libri VIII, według katalogu księgarskiego Argentorati 1621; Herodian, Historiarum libri VIII, Argentorati 1694.

${ }^{23}$ Drukarnia Oporina wydała książkę Kromera w latach: 1555, 1558 i 1568 . W katalogu podany jest błędny rok druku - 1574. Podobnie w wypadku przekładu na język polski - bibliografie i katalogi notują edycję krakowską z 1611 roku, w omawianym zaś spisie widnieje rok 1712.

${ }^{24}$ Z. Nowak, Wytwarzanie książek w Gdańsku w XVI i XVII wieku, w: tenże, Po stara księgę, s. $150-151$. 
thico-Cosacicum, 1652), Szymona Starowoskiego (Polonia nunc denuo recognita et aucta, 1652) i Jana Dymitra Solikowskiego (Commentarius brevis rerum Polonicarum, 1647). Tak duża partia książek Förstera jest zapewne wynikiem sporego zainteresowania mieszkańców Prus Królewskich, w tym Torunia, jego dorobkiem wydawniczym. Prace publikowane jego nakładem bardzo często występowały w księgozbiorach mieszkańców tej prowincji, o czym świadczy ich spora oferta na aukcjach bibliofilskich.

Poza wydawnictwami Förstera w katalogu było jeszcze sporo innych książek historycznych z XVII stulecia, w tym autorów już tu wspomnianych, jak J. Pastoriusa, którego w sumie Jansson posiadał aż 12 tytułów, S. Starowolskiego, S. Orzechowskiego ${ }^{25}$, a także Pawła Piaseckiego Chronica gestorum in Europa singularium (Amsterdam 1648), czy Salomona Neugebauera Historia Rerum Polonicarum (Hanower 1618).

Klienci księgarni Janssona zapewne szczególnie chętnie kupowali dzieła poświęcone dziejom prowincji i takie znalazły się też w omawianej ofercie. Była to m.in. popularna tu XIV-wieczna kronika ziemi pruskiej Piotra Duisburga, podana do druku w 1679 roku we Frankfurcie przez Christopha Hartknocha. Badacz ten przez kilka lat był profesorem w Toruńskim Gimnazjum Akademickiem, autorem kilku opracowań poświęconych dziejom Polski i Prus oraz Kościołowi w Prusach. Z tych wymienionych prac księgarz dysponował De respublica Polonica libri duo (Frankfurt i Lipsk 1687).

Z nowości wydawniczych, w tym wypadku książek drukowanych w XVIII stuleciu, w zakresie historii warto wspomnieć A.Ch. Załuskiego Epistolarum historico-familiarium Braniewo 1709-1711), pracę historyka i prawnika gdańskiego Gotfryda Lengnicha Hodierna Reipublicae Prutenae (Gdańsk 1728), historię Prus Jana Leo, proboszcza w Kiwitach i Lidzbarku, która doczekała się druku dopiero prawie po stu latach za sprawą biskupa Krzysztofa Szembeka. Niemal w tym samym czasie wyszły dwie edycje tego dzieła: w 1725 roku u jezuitów w Braniewie i w 1726 roku nakładem toruńskiego księgarza J.F. Hauensteina w Amsterdamie. Analizowany katalog notuje egzemplarz z 1725 roku. Jansson polecał jeszcze publikację miejscowego historyka Marcina Böhma Commentarius de interregnis in Regno Poloniae (Torun 1733), Imagines principum, regumque Poloniae (Braniewo 1721), podręcznik do historii Polski autorstwa Karola Bartolda, wykorzystywany w szkołach jezuickich oraz dwie popularne prace poświęcone historii Polski i Litwy Adama Ignacego Naramowskiego, jezuity i historyka: Facies rerum sarmaticarum (Wilno 1726) wraz z kontynuacją Signatores Regni signati (Warszawa 1727). Dzieje Rzeczypospolitej przedstawione w nich zostały na kanwie życiorysów królów, arcybiskupów, biskupów oraz kanclerzy koronnych i podkancle-

${ }^{25} \mathrm{Z}$ prac Pastoriusa można jeszcze wymienić dla przykładu: Florus Polonicus, seu Polonicae historiae epitome nova, Gedani 1679, Historiae Polonae pars prior de Vladislai IV regis extremis, secutoq in de interregno..., Gedani 1685 i Character virtutum variis, aliorum etiam qua veterum, qua recentium Autorum coloribus adumbratus, Dantisci 1680; S. Starowolskiego m.in.: Institutorum Rei Militaris libri VIII, Cracoviae 1639 i Vita et miracula serui Dei, Vincentii Kadlubkonis, Cracoviae 1642, a S. Orzechowskiego De institutione Regia ad Sigismundum Augustum libri duo, Cracoviae 1584 . 
rzych. Nie zabrakło w tym wykazie także najnowszego wydanie historii Polski Jana Długosza (Historiae Polonicae libri XII, Lipsk 1711-1712).

Uzupełnieniem oferty historycznej było kilka książek dotyczących numizmatyki i genealogii. W pierwszym przypadku warto wymienić pracę Dawida Brauna, Ausführlich-Historischer Bericht vom Polnisch- und Preussischen Münz-Wesen, drukowaną w Elblągu w 1722 r., w drugim dwa herbarze: Wacława Potockiego Poczet herbów szlachty Korony Polskiey y Wielkiego Xiestwa Litewskiego (Kraków 1696) i Herby polskie (Poznań 1705) Antoniego Swacha.

W wypadku książek o tematyce prawniczej księgarnia potencjalnym klientom również oferowała publikacje wydane głównie w XVII, a nawet w XVI stuleciu i dotyczące praw polskiego lub pruskiego. Z najstarszych warto odnotować trzy zestawienia aktów prawnych Królestwa Polskiego, jedno po łacinie dokonane przez Jakuba Przyłuskiego (Leges seu statuta ac privilegia Regni Poloniae, Kraków 1551), dwa w języku polskim: zestaw przepisów prawnych w układzie systematycznym Jana Herburta (Statuta Regni Poloniae, Gdańsk 1693) i opracowanie Stanisława Sarnickiego (Statuta y metrika przywileiow koronnych ięzykiem polskim spisane, Kraków 1594) ${ }^{26}$ oraz najpopularniejsze dzieło Bartłomieja Groickiego Porzadek sądów y spraw mieyskich prawa maydeburskiego (Kraków 1566). Prawo pruskie reprezentowała tu kolejna edycja prawa chełmińskiego z 1711 roku $\mathrm{z}$ drukarni jezuitów w Braniewie. Była to tzw. druga rewizja lidzbarska prawa chełmińskiego, która ukazała się z inicjatywy biskupa A.Ch. Załuskiego i prawnika Jana Jerzego Kunigka. Choć nie uzyskała ani sankcji sejmiku Prus Królewskich, ani królewskiej, to w praktyce stosowana była na terenie biskupstwa warmińskiego. Kunigk wzmiankowane wydanie uzupełnił różnymi normami prawa kanonicznego i zmienił dotychczasowe uszeregowanie ${ }^{27}$. Dużym zainteresowaniem w prowincji pruskiej cieszyła się też książka autorstwa związanego z Toruniem Jana Henryka Hauensteina Repertorium iuris pruthenici nimirum municipalis, culmensis emendati, correcti et revisi ut et iuris terrestris terrarum Prussiae, opublikowana w Gdańsku w 1730 roku. Był to bardzo pożyteczny i często wykorzystywany w praktyce sądowej usystematyzowany zbiór norm prawa sądowego i publicznego obowiązującego w Prusach Królewskich ${ }^{28}$.

$\mathrm{Z}$ opracowań poświęconych prawu księgarnia oferowała kilka prac Mikołaja Chwałkowskiego, w tym Regni Poloniae ius publicum (Królewiec 1684), dwutomową encyklopedię prawa, Iuris Regni Poloniae (Poznań 1702) Mikołaja Zalaszowskiego, Johanna Nixdorffa Opuscula juridico-practica Regnum Poloniae terrasque Prussiae (Gdańsk 1685) i Samuela Willenberga Selecta jurisprudentiae civilis (Gdańsk 1728).

${ }^{26}$ Więcej o nich zob.: J. Picur, O zbiorze Statuta y przywileye koronne z łacińskiego języka na polskie przełożone, nowym porzadkiem zebrane, autorstwa Jana Herburta, „Folia Iuridica Universitatis Wratislaviensis", 6 (2017) no 1, s. 174-182.

${ }^{27}$ Z. Zdrójkowski, Zarys dziejów prawa chetmińskiego 1233-1862, Toruń 1983, s. 33-34; J. Staszewski, Kunigk Jan Jerzy, w: PSB, t. 16, red. E. Rostworowski, Wrocław i in. 1971, s. 196-197.

${ }^{28}$ L. Pauli, Z. Zdrójkowski, Jan Henryk Hauenstein (1695?-1734) szlachcic tużycki, tawnik nowomiejski toruński, wydawca źródet prawa chetmińskiego, „Rocznik Toruński”, 18 (1988) s. 153155. 
W omawianej księgarni nie zabrakło też wydawnictw dydaktycznych, w tym słowników i podręczników do nauki języków. Były popularne dzieła Grzegorza Knapiusza, z których słownika łacińsko-polsko-grecko oferował księgarz egzemplarz z drugiej ręki, z edycji z lat 1643-1644, tezaurus łacińsko-polsko-niemiecki zaś posiadał $\mathrm{z}$ najnowszego wydania $\mathrm{z} 1726 \mathrm{roku}^{29}$. Z racji miejsca działania księgarni była ona dobrze zaopatrzona $\mathrm{w}$ wydawnictwa służące do nauki języka polskiego dla osób niemieckojęzycznych, w tym popularne, bliżej nieokreślone bibliograficznie w katalogu wydanie Vierzig Dialogi Mikołaja Volckmara, autora licznych gramatyk, rozmówek i słowników służących pomocą w nauce języka polskiego. Podobny charakter miała książka Jana Karola Woyny Kleiner Lustgarten worinn gerade Gänge zur Polnischen Sprache angewiesen werden (Gdańsk 1729). Te wydawnictwa uzupełniał wydany w Świdnicy w 1689 roku podręcznik Johanna Ernesti Polnisches Hand-Büchlein. Drugim językiem, do nauki którego można było nabyć w księgarni różne wydawnictwa, był język francuski. Zainteresowani jego poznaniem mieli do wyboru dwie prace Bartłomieja Malickiego: Klucz do ięzyka francuskiego, to jest gramatyka polsko-francuska (Kraków 1700) i Lexykon francusko-polski (Kraków 1701). Pierwsza z wymienionych jest zdecydowanie wyżej oceniana od wydanej rok wcześniej książki Francuza F.D. Duchenebillota, którą Jansson posiadał w edycji krakowskiej z 1716 roku $^{30}$.

W katalogu zostało odnotowanych także sporo różnych poradników. Nie zabrakło bardzo popularnej książki Jakuba Kazimierza Haura Skład abo skarbiec znakomitych sekretow oekonomiey ziemianskiey (Kraków 1693), pomocnej w prowadzeniu gospodarstwa wiejskiego, oraz pierwszej polskiej książki kucharskiej, Stanisława Czernieckiego Compendium ferculorum albo zebranie potraw. Praca ta po raz pierwszy ukazała się w Krakowie w 1682 roku. Księgarz toruński miał na składzie egzemplarze z drugiego wydania z 1730 roku. Zwraca uwagę jeszcze kilku poradników medycznych jak: Eliasza Beynonsa Świeżo przyczyniony mitosierny Samarytan albo przyjazno-braterska rada na wszelkie choroby... (Warszawa 1695), dwie książki wydane w Częstochowie przez paulina Łukasza Rudolfa Pollacza Vade mecum medicum to iest krótkie y doświadczone sposoby leczenia chorob rozmaitych (1721) i Compendium medicum auctum, to iest krotkie zebranie y opisanie chorob (1725), dwie drukowane w Krakowie: Krótkie zebranie lekarstw domowych wedlug Syreniusza z 1706 roku i Promptuarium medicum empiricum to iest krotkie opisanie [...] wnętrznych iako y powierzchownych męskich, białogłowskich y dziecinnych chorob, y sposoby leczenia ich proste y domowe ${ }^{31}$, a nawet Zielnik herbarzem Szymona Syreniusza. Jansson posiadał egzemplarz Zielnika z pierwszego i jedynego wydania krakowskiego z 1613 roku.

${ }^{29}$ G. Knapski, Thesauri Polonolatinograeci, t. 1-2, Kraków 1643-1644; tenże, Thesaurus latino-germanico-polonicus, Poznań 1726.

${ }^{30}$ W. Baczkowska, Malicki Bartlomiej Kazimierz, w: PSB, t. 19, red. E. Rostworowski, Wrocław i in. 1974, s. 320-321. Książka Duchenebillota w katalogu polecana była pod polskim tytułem: Nowy sposób do nauczenia się latwo y prętko czytać, pisać y gadać po francusku.

${ }^{31} \mathrm{~W}$ tym wypadku w katalogu księgarskim podany był rok druku 1708, gdy Bibliografia polska Estreicherów odnotowuje jedynie edycję z 1716 roku (t. 25, Kraków 1913, s. 284). 
Asortyment omawianej księgarni cechowała jeszcze wcale nie mała partia literatury pięknej. W ofercie były widoczne dzieła twórców starożytnych, które równie dobrze można było zaliczyć do literatury szkolnej. Co charakterystyczne, więcej było publikacji z XVII niż XVIII stulecia, a poza tym w propozycji Janssona znalazły się te prace $\mathrm{w}$ oryginale, ale $\mathrm{i} w$ przekładzie na język polski. W księgarni do wyboru znajdowało się z reguły po kilka wydań dzieł twórców rzymskich, w tym Horacego, Marcjalisa, Lukana, Wergiliusza i Owidiusza. Twórczość dwóch ostatnich była dostępna w oryginale oraz w dwóch przekładach na język polskich. W wypadku Wergiliusza była to Eneida przetłumaczona przez Andrzeja Kochanowskiego jeszcze w XVI wieku, Owidiusza zaś Jansson oferował dwa polskie przekłady: XVII-wieczny, dokonany przez Waleriana Otwinowskiego i z początku XVIII stulecia, będący dziełem Wojciecha Stanisława Chrościńskiego, którego w księgarni znajdował się również przekład Farsali Lukana. Literatura grecka $\mathrm{z}$ kolei była obecna w postaci bajek Ezopa.W tym wypadku do wyboru były dwa wydania polskojęzyczne z XVIII wieku: edycja krakowska z 1703 roku oraz nowy przekład Jana Stanisława Jabłonowskiego z 1731 roku, który ukazał się w ramach dwutomowej serii Biblioteki polskiej poetyckiej wydawanej przez Michała Abrahama Troca w Lipsku ${ }^{32}$.

Utwory twórców żyjących w stuleciach XVI i XVII również częściowo dostępne były w wersji polskojęzycznej. Warto tu wymienić Torquato Tasso Jeruzalem wyzwolona $\mathrm{w}$ przekładzie Piotra Kochanowskiego, tragikomedię pasterską Pastor Fido Giovanniego Battisty Guariniego wydaną sumptem Laurera, popularną historię o Telemaku Fraçoisa Fénelona w wierszowanym przekładzie J.S. Jabłonowskiego i Argenidę Johna Barclaya w tłumaczeniu W. Potockiego ${ }^{33}$. Polscy pisarze, których dzieła były obecne na półkach księgarni toruńskiej, to przede wszystkim Stanisław Herakliusz Lubomirski, reprezentowany aż dziesięcioma pozycjami, z których kilka wyszło spod pras miejscowej oficyny, Łukasz Górnicki i Maciej Sarbiewski ${ }^{34}$. Przykładem lekkiej, rozrywkowej lektury w asortymencie Janssona jest zbiór facecji Żarty abo krotofilne facecje, kolejna książka wydana nakładem jego poprzednika, Laurera. Sięgnął on po ten tytuł dwukrotnie: w 1695 i 1717 roku. W sprzedaży były egzemplarze z drugiej edycji.

${ }^{32}$ Vergilius, Aeneida, to iest o Aeneasu troiańskim ksiag dwanaście, Kraków 1590; J.S. Jabłonowski, Ezop nowy polski, to iest życie Ezopa, filozofa frygiskiego, sto i oko bajek, przy tym wybranych z ksiag rożnych autorow..., Lipsk 1731.

${ }^{33}$ T. Tasso, Goffred abo Jeruzalem wyzwolona, Kraków 1687; J.B. Guarini, Pastor fido, konterfekt wierny miłosci, Torun 1722; F. Fénelon, Historya Telemaka, syna Ulissesa, krola greckiego Itaku..., Sandomierz 1726; J. Barclay, Argenida, Warszawa 1697.

${ }^{34}$ Oferowane książki autorstwa Lubomirskiego to m.in.: Proznosc y prawda rady, Torun 1705 , Adverbia moralne abo o cnocie y fortunie xiqzeczka, Warszawa 1714 i Tobiasz wyzwolony, Toruń 1731. Ł. Górnickiego posiadał Dworzanina polskiego (Kraków 1639), a M. Sarbiewskiego Lyricorum libri IV (Frankfurt 1660 - to miejsce druku odnotowane jest w katalogu księgarskim, choć inne dostępne źródła, w tym Bibliografia polska Estreicherów najczęściej jako miejsce druku podają Wrocław ze znakiem zapytania lub w nawiasie. Por. K. Estreicher, Bibliografia polska, t. 27, Kraków 1929, s. 129). 
Zaprezentowana tu pokrótce oferta księgarni Janssona Möllera wskazuje na kilka kierunków jego działalności. Przede wszystkim wyraźnie widać, że księgarz na równi z nowymi wydawnictwami handlował książką antykwaryczną. Jego asortyment jest kolejnym przykładem dużego wyboru wydawnictw katolickich i książek polskojęzycznych w księgarniach toruńskich działających w pierwszej połowie XVIII stulecia. Jest to o tyle interesujące, że gdy przyjrzymy się dotychczasowym ustaleniom na temat księgozbiorów prywatnych torunian żyjących w tym okresie, to zauważamy, że ich właścicielami były przede wszystkim osoby należące do elity rządzącej i intelektualnej miasta, głównie protestanci. Zestaw wydawnictw polecanych przez tego księgarza i jego poprzedników, Hauenstaeina i Laurera, utwierdza nas w przekonaniu, że w omawianym czasie społeczność katolicka musiała w tym samym lub porównywalnym stopniu wykazywać zainteresowanie książkami, co protestancka. W wypadku Janssona związki z księgarnią Laurera były oczywiste, gdyż najpierw w niej pracował, a następnie ją prowadził. Porównując katalog z licytacji księgarni Laurera ${ }^{35}$ i omawiany spis, natrafiamy również na te same tytuły, np. Jansson oferował także kilka dzieł wydanych nakładem poprzednika, które jeszcze nie zostały rozsprzedane. Powtarzają się też inne książki, ale często zdarza się tak, że już w kolejnych edycjach, co świadczy o tym, że poprzednie znalazły nabywców.

\section{BIBLIOGRAFIA}

\section{Źródla archiwalne}

Archiwum Państwowe w Toruniu (AP Tor.)

sygn. Kat II, II, 41, Acta consularia, k. 68.

sygn. Kat. II, II. 45a, Acta consularia. Beilagen, k. 331.-333.

sygn. Kat. II, II 49, Acta consularia, k. 45-45v

Biblioteka Narodowa w Warszawie (BN)

rkps, III 3249, Listy S. Janssona Möllera do J. A. Załuskiego z Torunia z 9 III i 22 VI $1749 \mathrm{r}$.

\section{Źródła drukowane}

Catalogus librorum insignium qui in $b$. Joh. Christiani Laureri relictae viduae aedibus lata in platea sitis, vulgo Breiten Gasse, A. 1732. [rz.] die 3 [dopisane ręcznie] Oct. sqq. pro parata pecunia consveto auctionis more venales exponuntur, Thorunii [1732], egz. w WBP-Książnicy Kopernikańskiej w Toruniu, sygn. A-54 (1) adl. 29.

Catalogus librorum varii generis qui venales prostant in officina B. J. C. Laureri viduae curante Samuele Janssonio filio, Pars prima, Thorunii in lata Platea vulgo Breiten Gasse dicta 1738, [Toruń 1738], egz. w Bibliotece Katedralnej w Gnieźnie, sygn. BK 2699.

${ }^{35}$ Catalogus librorum insignium qui in b. Joh. Christiani Laureri relictae viduae aedibus lata in platea sitis, vulgo Breiten Gasse, A. 1732. [rz.] die 3 [dopisane ręcznie] Oct. sqq. pro parata pecunia consveto auctionis more venales exponuntur, Thorunii [1732]. 


\section{Opracowania}

Baczkowska Wanda, Malicki Bartłomiej Kazimierz, w: Polski Słownik Biograficzny, t. 19, red. E. Rostworowski, Wrocław i in. 1974, s. 320-321.

Brzozowski Mieczysław, Białobrzeski Marcin, w: Encyklopedia katolicka, t. 2, red. F. Gryglewicz, R. Łukaszyk, Z. Sułowski, Lublin 1976, kol. 365-366.

Buchwald-Pelcowa Paulina, Drukowi winniśmy oświecenie naszego wieku ...Rola ksiażki w drodze ku Oświeceniu, Warszawa 2003.

Buchwald-Pelcowa Paulina, Wstep, w: Psałterz Dawidów przektadania Jana Kochanowskiego, Warszawa 1985, s. I-VIII.

Estreicher Karol, Bibliografia polska, t. 12, Kraków 1891.

Estreicher Karol, Bibliografia polska, t. 21, Kraków 1906.

Estreicher Karol, Bibliografia polska, t. 25, Kraków 1913.

Estreicher Karol, Bibliografia polska, t. 27, Kraków 1929.

Estreicher Karol, Bibliografia polska, t. 33, Kraków 1939.

Imańska Iwona, Toruńskie aukcje ksiązek w XVIII wieku, Toruń 2007.

Imańska Iwona, Sprawy ksiażki w listach do Józefa Andrzeja Załuskiego od jego korespondentów z Prus Królewskich, w: Bracia Załuscy: ich epoka i dzieło. Zbiór studiów, red. D. Dukwicz, Warszawa 2011, s. 146-162.

Jaworek Aleksandra, Janssonius, w: Słownik pracowników książki polskiej, red. I. Treichel, Warszawa 1972.

Mocarski Zygmunt, Ksiązka w Toruniu do roku 1793. Zarys dziejów, Toruń 1934.

Nowak Zbigniew, Gdańska drukarnia Guillemota-Hünefelda w stużbie polskiej reformacji (1603-1652), w: tenże, Po stara księge sięgam ze wzruszeniem. Szkice z dziejów $i$ kultury ksiażki w Prusach Królewskich od XV do XVIII wieku, Gdańsk 2008, s. 165190.

Nowak Zbigniew, Wytwarzanie książek w Gdańsku w XVI i XVII wieku, w: tenże, Po stara księgę sięgam ze wzruszeniem. Szkice z dziejów i kultury książki w Prusach Królewskich od XV do XVIII wieku, Gdańsk 2008, s. 139-154.

Pauli Lesław, Zdrójkowski Zbigniew, Jan Henryk Hauenstein (1695?-1734) szlachcic tużycki, ławnik nowomiejski toruński, wydawca źródet prawa chetmińskiego, ,Rocznik Toruński”, 18 (1988) s. 153-157.

Picur Julia, O zbiorze Statuta y przywileye koronne z łacińskiego języka na polskie przełożone, nowym porzadkiem zebrane, autorstwa Jana Herburta, „Folia Iuridica Universitatis Wratislaviensis", 6 (2017) no 1, s. 167-192.

Rudnicka Jadwiga, Bibliografia katalogów księgarskich wydanych w Polsce do końca wieku XVIII, Warszawa 1975.

Staszewski Jacek, Kunigk Jan Jerzy, w: Polski Stownik Biograficzny, t. 16, red. E. Rostworowski, Wrocław i in. 1971, s. 196-197.

Tazbir Janusz, Skarga Piotr, w: Polski Słownik Biograficzny, t. 38, red. H. Markiewicz, Warszawa-Kraków 1997-1998, s. 35-43.

Zdrójkowski Zbigniew, Zarys dziejów prawa chetmińskiego 1233-1862, Toruń 1983. 


\section{CATALOGUE OF THE TORUŃ BOOKSELLER SAMUEL JANSSON MÖLLER FROM 1738 IN THE COLLECTION OF THE CATHEDRAL LIBRARY IN GNIEZNO}

\section{Summary}

The article presents the book range of Samuel Jansson Möller, a bookseller operating in Torun in the first half of the 18th century. The basis for its presentation was a book catalogue from 1738, included in the collection of the Cathedral Library in Gniezno. Jansson Möller became involved with Torun around 1725, when he took position in a thriving bookstore of Jan Christian Laurer, which, after his employer's death and at the request of the widow, was run by Möller until his own death around 1751 The catalogue contains nearly 1600 items, more than half of which were published in the 17 th century, $35 \%$ came from the first decades of the 18th century and the rest were 16th century prints, which proves that the bookseller merchandised used books as well as new publications. In many respects, the analysed catalogue demonstrated that Jansson's activity reflected that of his predecessor and another Torun bookseller of that period, Jan Fryderyk Hauenstein. Over $20 \%$ of the books in his catalogue were polonica, including many publications in Polish. Although the ruling and intellectual elites of the city at that time were mainly Protestants, Jansson also addressed his offer to Catholics, which shows that the Catholic community had to show interest in books to a comparable extent to the Protestant one.

Keywords: Jansson Möller Samuel; bookselling; book catalogue; Toruń; 18th century; Cathedral Library in Gniezno 